\title{
KONSEP BAHAGIA
}

\author{
Abdur Rohman \\ abdurrohman@iaipd-nganjuk.ac.id \\ Dosen IAI Pangeran Diponegoro Nganjuk
}

\begin{abstract}
Abstrak
Sepanjang manusia hidup, mereka kebingungan mencari satu kata yaitu 'bahagia.' Berbagai cara mereka tempuh untuk mendapatkan satu kata tersebut. Ada yang mengira berada pada kekuasaan, ada yang mengira berada pada kekayaan, ada yang mengira kebahagiaan itu di akhirat sana. Namun yang pasti, dimanakah kebahagiaan itu berada masih perlu ditelusuri lebih lanjut. Artikel singkat ini akan membahas tentang konsep bahagia. Kesimpulan penelitian ini terdapat enam 'syarat' agar seseorang bisa bahagia. Pertama, keadaan dan jiwanya menyatu. Kedua, kebahagiaan di ukur dari segi kejiwaan, bukan materi. Ketiga, kebahagiaan di ukur dari 'masalah', bukan prestasi. Keempat, jika tercapai apa yang diinginkan. Kelima, menempuh jalan yang lurus. Keenam, berfikir positif.
\end{abstract}

Kata kunci: barometer bahagia.

\section{Pendahuluan}

Hakikatnya seluruh manusia yang hidup di dunia ini hanya mencari satu kata yaitu 'bahagia'. Mereka ada yang berpandangan bahwa kebahagiaan itu dapat diraih dengan mengumpulkan harta benda, uang dan sebagainya. Pendapat ini tidak sepenuhnya salah, sebab manusia di dunia membutuhkan semua itu. Orang miskin mengira bahwa kebahagiaan itu kalau memiliki harta benda yang banyak. Rakyat jelata berfikir bahwa kebahagiaan itu saat menjadi pejabat. Anak-anak sekolah berfikir bahwa kebahagiaan itu kalau liburan. Ada pula yang berpendapat bahwa kebahagiaan itu adalah hidup rukun dan tentram bersama keluarga. Jika keluarganya bisa ayem-tentrem, maka dapat dikatakan bahwa keluarga tersebut bahagia, meskipun dengan rezeki yang pas-pasan. Tidak sedikit pula orang yang meyakini bahwa 
kebahagiaan itu terletak pada nilai spiritual, yaitu beribadah yang tekun kepada Tuhan agar kelak mendapatkan balasan surga. Pendapat ini juga tidak salah, sebab mereka berpandangan bahwa hidup di dunia ini hanya sementara, sedangkan yang abadi adalah kehidupan akhirat. Namun yang menjadi pertanyaan adalah apa dan bagaimana barometer bahagia itu sendiri. Siapakah yang benar diantara pendapat-pendapat di atas? Atau hal tersebut hanya mewakili bagian-bagian dari bahagia. Artikel singkat ini akan membahas tentang konsep bahagia. Di mana jika seseorang berada pada tataran ini, hampir dapat dipastikan akan bahagia.

\section{A. Jika Keadaan dan Jiwa Seseorang Menyatu}

Banyak orang yang berfikir bahwa bahagia itu di dapat jika seseorang memiliki banyak materi. Pemikiran ini tidak sepenuhnya salah. Sebab orang modern saat ini memang banyak yang sudah mengenyam filsaafat materialisme. Oleh karena itu, segala hal akan di ukur dari seberapa banyak ia memperoleh materi. Orang yang belajar (sekolah atau kuliah) akan dikatakan orang yang sukses manakala ia memperoleh banyak materi. Orang yang bekerja keluar negeri akan dikatakan sukses bahkan bahagia jika ia memperoleh banyak materi. Begitu pula dengan hal-hal yang lain. Ukuran bahagia itu seolah-olah hanya tertumpu pada materi. Oleh sebab itu, penulis akan mencoba menganalisa sedikit tentang konsep bahagia yang sedang diburu oleh semua orang.

Dalam pandangan penulis, bahagia itu dapat di ukur jika jiwa (pikiran) dan keadaan seseorang menyatu. Mungkin pernyataan ini cukup sulit jika hanya sebatas statement. Perlu contoh agar pernyataan ini menjadi jelas dan mudah dipahami. Menyatunya keadaan dan jiwa seseorang contohnya adalah orang yang makan. Orang yang makan nasi pecel tidak akan merasakan nikmat jika ia memikirkan nasi ayam. Orang yang makan nasi ayam tidak akan merasakan nikmat jika ia memikirkan sate. Orang yang makan sate tidak akan merasakan nikmat jika ia memikirkan Pizza Hut. Semua hal tersebut dapat dirasakan bahagia oleh seseorang jika orang yang makan tersebut mampu menikmati apa yang ada, bukan apa yang tidak ada. 
Dalam persoalan tempat juga demikian. Orang yang berada di perantauan mungkin akan berfikir 'Jika saya lebaran kali ini di rumah, saya bisa berkumpul dengan keluarga, bersama-sama dengan teman, saling bercanda, silaturahim dan sebagainya.' Semua anganangan itu mereka pikirkan pada saat seseorang tidak berada di rumah, atau lebih tepatnya di perantauan. Begitu pula sebaliknya. Jika orang yang ada di perantauan tersebut sedang di rumah, mereka berkata 'Di rumah bingung, tidak ada kemasukan, hanya ada pengeluaran. Enak di perantauan, uang terus mengalir, kerjaan lancar.' Pemikiran seperti ini akan menjadikan seseorang tidak bahagia dengan keadaannya. Oleh karena itu, kebahagiaan dapat di ukur jika pemikiran atau jiwa seseorang mampu menyatu dengan keadaannya.

Dalam kedua contoh tersebut, mengapa tidak dinikmati Keadaannya. Pada saat mereka berada di rumah, mengapa tidak menikmati suasana rumah Menikmati saat-saat berkumpul dengan keluarga, teman, bersilaturahim dengan sesama. Begitu juga pada saat di perantauan. Mengapa tidak menikmati keadaannya banyak kerjaan, banyak kemasukan dan mengingat di luar sana tidak sedikit orang yang tidak mendapatkan pekerjaan. Jika keadaan dan jiwa seseorang mampu menyatu, ia akan bahagia.

B. Kebahagiaan Adalah Urusan Kejiwaan

Tolak ukur bahagia sebenarnya terletak pada jiwa. Seorang petani akan sangat menikmati makanan yang dikirim dari rumah saat mereka menggarap sawah, baik pada saat membajak sawah atau pada saat musim panen. Kebahagiaan tersebut tercapai meskipun dalam pandangan orang lain terlihat profesi rendahan, tidak menghasilkan atau bahwa sering rugi. Akan tetapi dengan menu yang cukup sederhana, bahan makanan yang sangat sederhana pula seorang petani tetap merasakan kebahagiaan dan menikmati makanan yang dikirimkan oleh keluarga yang masak di rumah. Nasi tiwul (nasi yang terbuat dari singkong) misalnya dengan lauk gerib (ikan asin) dan

1 Abdur Rohman, Sufi Modern: Kombinasi dan Landingisasi Gagasan Sufi. Yogyakarta: Divo Nusantara, 2016, 86. 
sambal teri yang cukup pedas sudah cukup untuk merasa puas dan menikmati sungguh-sungguh makanan tersebut tanpa berfikir kesana-kemari tentang makanan yang tidak ada. Keadaan perut yang lapar, alam yang asri, dibumbui dengan sedikit guyonan dari sesama petani yang menikmati sarapan pada saat itu menambah suasana semakin hangat dan bahagia. Begitulah sejatinya bahagia, bukan terletak pada materi, namun keadaan jiwa yang dialami oleh seseorang. Jika memang materi adalah yang menjadi tolak ukur kebahagiaan, mengapa tidak terjadi banyak kasus bunuh diri pada penduduk negara yang miskin? Tapi malah sebaliknya! banyak orang yang bunuh diri justru datang dari negara-negara yang kaya secara materi. $^{2}$

\section{Bahagia di Ukur dari Problem, Bukan Prestasi}

Jika seseorang mencapai sesuatu derajat, misalnya menjadi menteri, PNS, polisi dan sebagainya, apakah semua orang yang mencapai level tersebut pasti bahagia? Belum tentu! Apakah orang yang kaya pasti bahagia? Belum tentu. Semua itu jika di ukur dengan pencapaian prestasi jawabanya masih sama 'belum tentu.' Namun jika tolak ukur bahagia adalah dari 'problem' maka jawabannya 'pasti bahagia.' Ilustrasi berikut mungkin akan menggambarkan secara gamblang bahwa konsep bahagia itu dapat di ukur dari problem. Contohnya adalah orang yang cerai. Jika dalam sebuah keluarga

${ }^{2}$ Data-data jumlah bunuh diri di berbagai dunia dapat dilihat dalam buu-buku berikut dengan kesimpulan bahwa banyak orang bunuh diri justru di negara-negara maju, bukan negara miskin. Lihat berbagai data dalam: Syaikh Muhammad bin Ibrahim alHamd. Terj. Muhibbur Rahman, Cara Bertaubat Menurut al-Qur'an dan Sunnah. Jakarta: Pustaka Imam Syafi'i, 2007, 385. Yang mengutip pedapat Malik Badri dalam kitab Afwalu Syamsil Hadharah al-Gharbiyyah min Näfizat al-Jaräim, 106-107.; Mahmudin, Menemukan Kebanaran Islam. Yogyakarta: Gava Media, 2006, 219; Lynn Sholes and Joe Moore, terj. Istiani Prajoko, The Lat Screet. Jakarta: Serambi Ilmu Semesta, 2011, 206207; Murtadha Muthahhari, terj. Agus Efendi Keadilan Ilabi: Asas Pandangan Dunia Islam. Jakarta: Mizan, 2009, 88. Luh Ketut Suryani, Cokorda Bagus Jaya Lesmana, Hidup Bahagia, Perjuangan Melawan Kegelapan. Jakarta: Pustaka Obor Populer, 2008, 5-8. Lihat, Abdur Rohman, Islam akan Menang: Analisa Kemenangan Agama Islam di Masa Depan. Kediri: Parafrasa dan Santri Salaf Press, 2013, 95. 
terjadi perceraian, maka dapat di pastikan ia tidak bahagia. Jika dalam keluarga sering bertengkar, maka dapat dipastikan ia tidak bahagia. Jadi, orang yang bahagia adalah mereka yang mampu meminimalisir persoalan. Baik persoalan pribadi, keluarga, maupun persoalan sosial. Semakin pandai seseorang dalam meminimalisir masalah, maka semakin besar pula kemungkinan dia menjadi bahagia.

\section{Jika Tercapai Apa yang Diinginkan}

Penulis tidak memungkiri adanya keterkaitan faktor eksternal yang mempengaruhi kebahagiaan seseorang. Meskipun di atas penulis menjelaskan bahwa persoalan bahagia sebenarnya adalah terletak pada kejiwaan seseorang, akan tetapi kejiwaan tersebut juga dapat dipicu oleh faktor lain seprti halnya materi ataupun pencapaian sesuatu. Bagi penulis, bahagia itu ada porsinya. Memang penentunya adalah pada kejiwaan seseorang, namun ada pula porsi lain yang terkait dengan materi dan sebagainya.

Jika seseorang mencapai sesuatu yang di harapkan, baik berupa materi, pangkat, pekerjaan yang lebih layak dan sebagainya, itu semua memang faktor yang menyebabkan bahagia. Namun perlu di ingat bahwa kebahagiaan yang timbul dari materi itu tidak akan bersifat abadi. Sebab materi itu sendiri juga tidak abadi. Kekuatan bahagia orang yang memiliki motor tidak akan melebihi 10 tahun (secara umum). Sebab, dalam jangka waktu yang relatif singkat, baik satu atau dua tahun kemudian akan ada model baru lagi yang lebih bagus dan lebih canggih.

Orang tidak akan mungkin selamanya akan mencintai barang yang usang, apalagi sering kali rewel. Oleh sebab itu, kebahagiaan yang di sandarkan kepada materi memiliki batasan waktu. Kendaraan akan usang di makan waktu, jabatan akan di makan waktu, sedangkan jiwa seseorang akan ada sepanjang waktu. Semua orang mengharapkan cita-cita, harapan atau doanya terkabul. Namun, Yang menjadi persoalan adalah 'mengapa harapan (doa) seseorang tidak langsung terwujud?' padahal Tuhan sudah berjanji 'ud'uni astajib lakum [Ghäfir 40:60]' berdoalah pada-Ku, niscaya akan Ku kabulkan permintaanmu. 
Dalam kasus seperti ini hendaknya dipertimbangkan hal-hal sebagai berikut: Pertama, doa yang tidak langsung di kabulkan oleh Tuhan bisa jadi orang yang akan di kabulkan doanya tersebut tidak akan mampu menanggung apa yang ia doakan. Seperti halnya anak kecil yang baru berumur 10 tahun meminta moge (motor gede). Tentu orang tua yang memiliki anak tersebut tidak akan langsung mengabulkanya karena anak tersebut belum kuat untuk menanggung atau mengendalikan moge tersebut. Bisa jadi, meskipun orang tua anak tersebut mampu membelikan apa yang diminta anak, akan tetapi dengan keadaan si anak tersebut tidak memungkinkan untuk di wujudkan. Kedua, tidak dikabulkannya doa tersebut bisa jadi orang yang meminta tersebut diberi ganti yang lain. Contoh anak kecil yang menginginkan motor tersebut. Bisa jadi oleh orang tuanya digantikan dengan barang baru yang lebih tepat dan bermanfaat bagi si anak tersebut.

Ketiga, bukan permohonannya yang tidak di kabulkan, akan tetapi di tunda sampai pada batas waktu yang layak untuk diberikan. Contoh anak kecil di atas juga dapat mewakili dari doa yang tidak di kabulkan. Keempat, ketidak-layakan orang yang di beri doa. Bisa jadi orang yang berdoa dengan keadaannya kurang sesuai sehingga doa itu tidak menjadi kenyataan. Misalnya orang biasa yang tidak sekolah, orang biasa yang tidak ikut organisasi atau masuk dalam partai politik, bukan tokoh masyarakat dan bukan apa-apa, ia berdoa ingin menjadi presiden. Jika hal tersebut semua dikembalikan kepada Tuhan, maka tidak ada yang tidak mungkin. Semuanya serba mungkin. Namun pertanyaannya adalah berapa persen kemungkinan itu? Tentu jawabannya sangat kecil. Oleh sebab itu, yang tidak memungkinkan doa tersebut tidak terealisasi adalah keadaan orang yang mengucapkan doa tersebut.

E. Jalan yang Lurus

Konsep bahagia selanjutnya adalah dengan menempuh jalan yang lurus. Jalan lurus dalam pandangan penulis memiliki dua sisi, lurus dalam pandangan agama dan sosial. Pertama, lurus dalam pandangan agama adalah orang tersebut dapat bahagia jika ia tidak 
melanggar aturan agama. Misalnya jika seseorang melanggar aturan agama seperti minum-minuman keras, imbasnya adalah kepada diri pelaku itu sendiri, bahkan orang lain. Segala apa yang ia lakukan akan memiliki efek. Efeknya, bisa jadi orang yang meminum minuman keras tersebut dikatakan bahagia pada saat itu, namun kebahagiaan itu tidak akan bertahan lama. Sebab, orang yang mabuk akan mengalami penyakit jasmani, rohani dan sosial. Penyakit jasmani yang diakibatkan dari meminum minuman keras salah satunya hilangnya fungsi akal secara permanen.

Akal adalah pemberian Tuhan yang paling utama dibandingkan dengan yang lain. Dengan akal inilah orang bisa berfikir dan bisa membedakan antara yang baik dan yang buruk sekaligus yang membedakan dengan makhluk yang lain seperti hewan dan malaikat. Jika keistimewaan dan kemuliaan akal yang diberikan Tuhan ini diracuni, maka ia sendiri akan menderita sehingga akibatnya tidak akan bahagia. Penyakit rohani atau kejiwaan yang disebabkan oleh minuman keras adalah seseorang akan mengalami kegelisahan pada saat ia mengkonsumsi barang tersebut. Sedangkan penyakit sosial yang ditimbulkan adalah mereka yang mengkonsumsi minuman keras akan dijauhi oleh lingkungan sosialnya. Hal inilah yang menyebabkan orang tidak akan bahagia, sebab ia melanggar aturan agama.

Contoh kedua adalah orang yang melanggar agama dengan berjudi. Jika seseorang menang judi, ia mendapat banyak uang dari judi tersebut, maka uang dari judi tersebut akan hilang dengan cepat. Hal ini dapat dianalisa melalui beberapa faktor. Faktor pertama karena adanya 'rumus' bahwa 'sesuatu yang didapat secara mendadak maka hilangnya juga akan mendadak'. Hal tersebut menjadi nyata sebab orang yang menang judi akan kehilangan uanganya dengan cepat karena orang yang mendapatkan sesuatu dengan tanpa jerih payah, membelanjakannya juga tidak eman. Faktor kedua yang menjadikan uang tersebut cepat hilang adalah egoisitas. Rasa penasaran yang tinggi terhadap 'kemenangankemenangan yang akan datang' membuat para pelaku judi tidak enggan untuk kembali lagi dalam melakukan hal tersebut. Sangat 
jarang di jumpai orang yang menang judi, kemudian ia menang, lalu dengan kemenangan tersebut ia tidak akan judi lagi. Kebanyakan justru sebaliknya. Kemenangan tersebut justru membuat ia lebih semangat dan penasaran akan kemenangan yang akan datang.

Kedua, lurus dalam pandangan sosial. Manusia adalah makluk sosial yang bergantung dengan orang lain. Seseorang yang makan sesuap nasi membutuhkan banyak pihak yang ikut serta dalam proses makan tersebut. Ia butuh petani yang menanam padi, butuh buruh angkut untuk dipindahkan ketempat penggilingan, butuh jasa penggilingan, butuh jasa pembuat alat masakan, butuh listrik untuk menyalalakan alat tersebut. Semua itu melibatkan banyak ahli dan banyak tenaga kerja dan tidak akan mungkin semua bidang tersebut dikuasai oleh satu orang. Manusia membutuhkan yang lain, karena fitrah manusia adalah makhluk sosial yang membutuhkan yang lain. Kebahagiaan sosial misalnya jika seseorang mampu berinteraksi dengan lingkungan dan kehadirannya mampu memberikan manfaat bagi lingkungannya (khair al-nās anfa'u li al-nās).

Jika seseorang makan enak, tentu makanan tersebut akan lebih nikmat jika ada orang lain yang menemani. Orang akan lebih bahagia jika lingkungannya ikut menikmati kebahagiaan itu, sebab keberadaan lingkungan masyarakat dibutuhkan oleh manusia. Jika ada seseorang yang memiliki kelebihan makanan sedangkan dilingkungannya ada yang membutuhkan, seolah-olah kebahagiaan tersebut 'ada yang kurang.' Oleh sebab itu, kebahagiaan akan terapai jika seseorang bisa berbaur, berbagi dan berinteraksi dengan baik terhadap lingkungannya.

Jalan yang tidak lurus membatasi seseorang. Tidak sedikit ditemukan sebauh cerita yang menyatakan bahwa ada seseorang yang dicopet, dirampok, dibawa kabur hartanya oleh orang lain, baik orang dekat maupun orang yang tidak di kenal, korupsi dan sebagainya. Semua itu sesungguhnya membuat gelisah orang yang menjadi korban namun membuat 'bahagia' orang yang membawa uang tersebut. Namun perlu di ingat bahwa bahagia sejati bukanlah pada 'keberhasilan' seseorang saat membawa kabur uang haram tersebut. Justru dengan membawa uang tersebut sesungguhnya ia 
membatasi dirinya untuk bahagia. Jika uang yang bibawa kabur tersebut adalah milik teman, maka pertemanan itu akan rusak dan ia tidak akan 'berani' untuk bertemu dengan teman yang ia tipu tersebut. Dengan tidak berani bertemu orang tersebut, maka kebahagiaan itu menajadi hilang.

Jika yang ia bawa kabur adalah uang desa, maka ia tidak akan berani kembali lagi kepada desa tersebut. Jika ia tidak berani kembali lagi kedesa itu, maka secara otomatis ia tidak memiliki tempat tinggal yang 'mapan'. Jika tidak memiliki tempat tinggal yang mapan, maka secara otomatis biaya hidup yang dikeluarkan jauh lebih besar dibandingkan dengan hidup di rumah sendiri. Hal ini belum lagi jika dikaitkan dengan pekerjaan. Orang yang lari dari tanggung jawab secara psikologis ia akan terganggu dengan larinya tersebut dan ia akan menadapatkan masalah baru dalam pelariannya itu.

Hal itulah yang menjadikan ia tidak bahagia karena terbebani oleh perbuatannya sendiri yang membatasi dirinya untuk menjalani kehidupan yang lurus. Semakin banyak ia menjalani perbuatan yang tidak lurus, semakin banyak pula 'investasi' negatif yang ia tanam. Semakin besar jumlah nominal yang ia bawa lari, semakin besar pula risiko dan beban yang ia tanam, sehingga tidak menutup kemungkinan di kemudian hari, orang yang dirampas haknya tersebut akan menuntut balas.

\section{F. Ukuran Bahagia dari Sisi Pelaku, bukan Pengamat}

Banyak orang yang mengukur bahagia itu dari apa yang ia pandang. Bagi penulis, ukuran bagagia itu bukan dari pengamatan, tetapi dari kenyamanan orang yang menjalani kehidupan. Tidak sedikit orang memandang kehidupan orang desa yang miskin dipandang kurang bahagia. Mereka memandang bahwa makanan yang dikonsumsi ala kadarnya, rumahnya juga sederhana, penghasilannya juga pas-pasan. Namun semua itu dinilai oleh orang luar, bukan orang dalam (pelaku).

Beda halnya dengan pelaku, ukuran bahagia itu sangat personal. Pola kehidupan di desa seperti yang tertulis di atas, memang terkesan kurang bahagia. Namun sebaliknya, dengan 
kesederhanaannya tersebut, pola pikirnya juga sederhana. Hal inilah yang menjadikan mereka tetap survive dan bahagia. Bagi penulis, pola pikir inilah yang akan menentukan bahagia. Orang memiliki kehidupan sederhana, penghasilan sederhana, ia juga akan adaptasi dengan menyederhanakan kebutuhan hidupnya. Misalnya, bagi orang desa, hidup pas-pasan hanya untuk makan minum, bagi mereka itu dinikmati seadanya. Pagi-pagi ngobrol dengan tetangga di warung kopi, habis itu berangkat ke sawah bareng-bareng untuk mengerjakan garapannya di sawah, siang pulang sebentar untuk istirahat dan kembali lagi ke sawah hingga sore. Setelah itu malamnya ngobrol lagi dengan tetangga sambil ngopi dan menikmati malammalam dengan kesederhanaan.

Pola pikir mereka tidak muluk-muluk. Mereka tidak memikirkan 'bagaimana caranya mendapatkan uang bermilyar-milyar' namun pola pikir mereka sederhana, asal keluarga sudah cukup makan, pertaniannya digarap dengan baik, harapan panen bisa melimpah, itu sudah cukup membuat orang desa bahagia. Bisa jadi dari sisi pengamat kesederhanaan tersebut adalah kekurangan, akan tetapi dari segi pelaku, hal tersebut sudah menjadi kebiasaan dan telah beradaptasi sehingga biasa-biasa saja.

\section{G. Berfikir Positif}

Sesungguhnya poin ini tidak jauh berbeda dengan poin pertama, namun yang membedakan adalah contoh kasus yang di ambil. Hidup ini adalah pilihan. Ada orang yang menjadi pedagang, ada yang ingin menjadi PNS, pejabat dan sebagainya. Apapun pilihan hidup atau kenyataan hidup yang ia jalani sesungguhnya adalah pilihan. Sedangkan setiap pilihan memiliki sisi positif dan negatif. Jika orang berfikir negatifnya, maka ia tidak akan bahagia. Namun jika seseorang berfikir positifnya, maka ia akan bahagia.

Seorang mahasiswa dengan beban tugas perkuliahan yang cukup berat akan membuat ia mengeluh atau bahkan tidak sedikit yang lari dari tugas. Sikap demikian sebenarnya dapat diminimalisir dan dijadikan sebagai bahan untuk membuatnya bahagia. Kebahagiaan itu jika yang dipikirkan adalah positifnya. Seorang 
mahasiswa tersebut akan bahagia dengan keadaannya jika ia berfirkir di luar sana tidak sedikit orang yang tidak mampu menempuh kuliah karena keterbatasan biaya dan sebagainya.

Di luar sana banyak orang tua yang berharap memiliki anak sarjana. Namun mengapa orang yang sudah kuliah mengeluh? Itu karena ia berfikir 'negatifnya'. Coba kalau ia berfikir positifnya, tentu hasilnya akan berbeda. Misalnya, beranggapan bahwa dosen yang memberikan tugas tersebut agar mahasiswa memiliki pengetahuan luas dan trampil dalam mengerjakan tugas. Pengerjaan tugas yang baik dan benar ini jika dilakukan dengan terus-menerus oleh mahasiswa, maka imbal baliknya juga akan kembali kepada dirinya sendiri sehingga memiliki pengetahuan yang luas dan keterampilan akademik yang dapat di andalkan.

Seorang yang menjadi PNS misalnya akan mengeluh saat mereka terkena aturan check clock ataupun penyusunan laporan. Hidup seakan seperti robot sebab dari pagi hingga sore harus berada di tempat kerja. Waktu untuk teman, keluarga atau bahkan masyarakat, mau-tidak mau harus dikalahkan dengan aturan tersebut. Jika orang tersebut berfikir negatifnya, maka ia hanya akan mengeluh dengan kondisinya. Mengapa tidak berfikir bahwa di luar sana masih banyak orang yang belum bekerja, masih banyak orang yang memiliki penghasilan lebih rendah, masih banyak orang yang mengimpikan untuk jadi PNS namun belum jadi juga.

Pada saat pendaftaran PNS di buka, berapa banyak orang yang mendaftar? Semua itu mendambakan PNS. Namun mengapa orang yang sudah menjadi PNS mengeluh dengan aturannya? Persoalannya adalah sederhana, karena ia tidak berfikir positifnya profesi dia. Coba jika difikirkan bahwa ia sudah mendapatkan gaji yang layak, berbagai tunjangan, dan fasilitas-fasilitas lain yang tidak terdapat dalam profesi lain. Oleh sebab itu, ia akan menikmati pekerjaan atau keadaan seseorang jika ia berfikir positif terhadap keadaannya sehingga ia menjadi bahagia. Semua itu adalah konsekuensi dari profesi yang ia jalani dan telah disesuaikan dengan imbal balik yang diterima. 


\section{Kesimpulan}

Artikel singkat ini menyimpulkan enam hal. Pertama, kebahagiaan itu di dapat jika keadaan seseorang dan jiwanya menyatu. Kedua, kebahagiaan itu diukur dari kejiwaan seorang pelaku, bukan pengamat. Ketiga, kebahagiaan diukur dari kecerdasan seseorang meminimalisir 'masalah', bukan sekedar pencapaian prestasi. Keempat, jika tercapai apa yang diinginkan, dengan catatan melalui cara yang benar. Kelima, menempuh jalan yang lurus, dalam arti tidak melanggar aturan yang berlaku, baik aturan agama, negara ataupun sosial. Keenam, berfikir positif tentang keadaannya. 
Spiritualis: vol. 4, no. 1, Maret 2018 |13

\section{DAFTAR PUSTAKA}

Lynn Sholes and Joe Moore, terj. Istiani Prajoko, The Lat Screet. Jakarta: Serambi Ilmu Semesta, 2011.

Mahmudin, Menemukan Kebanaran Islam. Yogyakarta: Gava Media, 2006.

Muthahhari, Murtadha. terj. Agus Efendi Keadilan Ilabi: Asas Pandangan Dunia Islam, Jakarta: Mizan, 2009.

Rohman, Abdur. Islam Akan Menang: Analisa Kemenangan Islam di Masa Depan. Kediri: Parafrasa dan Santri Salaf Press, 2013.

-------, Sufi Modern: Kombinasi dan Landingisasi Gagasan Sufi. Yogyakarta: Divo Nusantara, 2016.

Suryani, Luh Ketut dan Cokorda Bagus Jaya Lesmana. Hidup Babagia, Perjuangan Melawan Kegelapan. Jakarta: Pustaka Obor Populer, 2008.

Syaikh Muhammad bin Ibrahim al-Hamd. Terj. Muhibbur Rahman, Cara Bertaubat Menurut al-Qur'an dan Sunnah. Jakarta: Pustaka Imam Syafi'i, 2007. 